\title{
PENGARUH PROFITABILITAS, CAPITAL ADEQUACY RATIO, DAN DIVERSIFIKASI PENDAPATAN TERHADAP RISIKO BANK (Studi Pada Perusahaan Perbankan Yang Terdaftar Di Bursa Efek Indonesia)
}

\author{
Ulan Lestiana Putri \\ Risal Rinofah \\ Mujino

\begin{abstract}
Universitas Sarjanawiyata Tamansiswa
risal.rinofah@ustjogja.ac.id
\end{abstract}

\begin{abstract}
The research aims to determine the influence of profitability, capital adequacy ratio and revenue diversification against the risk of bank. This study used case study on the banking companies and used the banks listed on the Indonesia Stock Exchange (IDX) in period 2014-2018 as the population. The research used purposive sampling technique. The data analysis techniques used statistical descriptive test, classical assumption testing (normality test, autocorrelation test, multicolinearity test, and heteroskedasticity test). Hypothesis testing used multiple linear regression analysis. The data quality testing used $\mathrm{T}$ test, $\mathrm{F}$ test and determination test. The results showed that profitability, capital adequacy ratio partially had a negative influence on the bank risk, while the revenue diversification had a positive influence on the bank risk. Simultaneously, the profitability, capital adequacy ratio, and diversification of revenues had a significant influence on the bank risk.
\end{abstract}

Keywords: Profitability; Capital Adequacy Ratio; Revenues Diversification; Bank Risk.

\section{PENDAHULUAN}

Industri perbankan adalah industri yang memiliki risiko, karena mengelola uang nasabah yang diputar lalu dibentuk dalam berbagai investasi, seperti pembelian suratsurat berharga, pemberian kredit, dan penanaman dana lainya (Nusantara, 2009). Bank dapat dianalogikan sebagai urat nadi bagi perekonomian dan merupakan badan usaha yang mengkaitkan berbagai pihak sehingga perbankan menjadi industri yang perlu diamati perkembangan kinerjanya (Rinofah, 2014). Sementara menurut Kasmir (2008) bank merupakan lembaga keuangan yang kegiatannya menghimpun dana dari masyarakat dalam bentuk simpanan kemudian menyalurkan kembali ke masyarakat, serta memberikan jasa-jasa bank lainnya.

Profitabilitas adalah rasio yang di gunakan untuk menilai sejauh mana perusahaan menghasilkan laba pada tingkat yang dapat diterima (Fahmi, 2011). Profitabilitas dapat di hitung dengan beberapa rasio keuangan, salah satunya adalah return on asset (ROA). Syahyunan (2004) menjelaskan bahwa semakin besar ROA, mengindikasi bahwa semakin besar pula tingkat keuntungan yang diperoleh oleh perusahaan, sehingga kemungkinan suatu perusahaan dalam kondisi 
bermasalah semakin kecil. Capital Adequacy Ratio (CAR) menurut Dendawijaya (2005) merupakan rasio yang menunjukan kemapuan bank menggunakan modal sendiri tanpa memperoleh dana dari sumber diluar bank (pinjaman, dana pihak ketiga dan lain sebagainya) untuk membiayai seluruh aktiva yang mengandung risiko seperti surat berharga, penyaluran kredit, dan tagihan pada bank lain. Selanjutnya, semakin tinggi modal yang dimiliki oleh suatu bank, maka semakin mudah bagi bank untuk membiayai aktiva yang mengandung risiko, sehingga risiko yang ditanggung oleh bank akan menurun.

Diversifikasi pendapatan menurut Kasmir (2004) fee based income merupakan keuntungan yang diperoleh dari transaksi yang diberikan dalam jasa-jasa bank lainnya atau spread based (selisih antara bunga simpanan dengan bunga pinjaman). Kekurangan dari studi yang dilakukan oleh Rinofah (2014) yaitu belum menggunakan variabel seperti jenis kepemilikan yang meliputi manajerial, institusional, swasta dalam negeri maupun asing dan pemerintah yang diidentifikasi memiliki perbedaan karakter dalam pengelolaan bank maupun preferensi risiko. Alasan memilih bank sebagai objek penelitian karena bank menyajikan laporan keuangan secara terus-menerus secara rutin pada periode tertentu sehingga dapat dijadikan sampel pada penelitian ini dan memiliki fungsi membantu dalam pembangunan ekonomi masyarakat.

Berdasarkan uraian di atas, maka perumusan masalah dalam penelitian ini sebagai berikut:

1. Apakah Profitabilitas berpengaruh negatif terhadap Risiko Bank?

2. Apakah Capital Adequacy Ratio berpengaruh negatif terhadap Risiko Bank?

3. Apakah Diversifikasi Pendapatan berpengaruh negatif terhadap Risiko Bank?

4. Apakah Profitabilitas, Capital Adequacy Ratio, dan Diversifikasi Pendapatan berpengaruh terhadap Risiko Bank?

\section{TINJAUAN PUSTAKA}

\section{Landasan Teori}

\section{Bank}

Menurut Undang-Undang Perbankan nomor 10 tahun 1998 tentang perbankan, mendefinisikan bank sebagai badan usaha yang menghimpun dana dari masyarakat dan menyalurkannya kepada masyarakat dalam bentuk kredit dan bentuk-bentuk lainnya yang bertujuan untuk meningkatkan taraf hidup rakyat banyak. Definisi lain yang disampaikan oleh Ikatan Akuntan Indonesia (2002) mengatakan bahwa bank adalah lembaga yang berperan sebagai perantara keuangan (financial Intermediary) antara pihak yang memiliki dana dan pihak yang memerlukan dana, serta lembaga yang berfungsi melancarkan lalu lintas pembayaran.

\section{Risiko Bank}

Menurut Peraturan Bank Indonesia nomor 5 tahun 2003 terdapat 8 jenis risiko pada industri perbankan, yaitu: Pertama, risiko kredit, merupakan risiko yang ditibulkan akibat kegagalan klien dalam memenuhi kewajibannya. Kedua, risiko pasar, adalah risiko yang ditimbulkan akibat variabel pasar (adverse movement) bergerak dari portofolio yang dimiliki oleh bank, sehingga dapat merugikan bank. Ketiga, risiko likuiditas, adalah risiko yang ditimbulkan akibat tidak mampuanya bank dalam membayar kewajibanya pada saat jatuh tempo (funding liquidity risk) atau karena suatu transaksi tidak dapat dilaksanakan pada harga pasar yang terjadi (asset liquidity risk). Keempat, risiko operasional, adalah risiko yang ditimbulkan akibat tidak berfungsinya proses internal atau ketidak cakapan sumber daya manusianya. Kelima, risiko hukum, adalah risiko yang di akibatkan karena kelemahan aspek yuridis atau kelemahan kontrak. Keenam, risiko reputasi, adalah risiko yang diakibatkan oleh publikasi negatif berkaitan 
dengan bank atau persepsi negatif terhadap bank. Ketujuh, risiko strategik, adalah risiko yang diakibatkan karena adanya pelaksanaan dan penetapan strategi bank yang, pengambilan Keputusan bisnis yang tidak tepat atau kurangnya kepekaan bank terhadap perubahan kondisi lingkungan eksternal. Kedelapan, risiko kepatuhan, adalah risiko yang diakibatkan karena ketidak patuhan bank terhadap ketentuan peraturan atau perundangan yang berlaku.

\section{Profitabilitas}

Profitabilitas merupakan kemampuan perusahaan dalam memperoleh keuntungan (Kasmir, 2014). Menurut Prasanjaya (2013) mengukur tingkat profitabilitas memiliki tujuan untuk menjamin apakah keuntungan yang ditargetkan oleh perusahaan dalam beberapa periode telah tercapai. Dalam penelitian ini, rasio yang digunakan untuk mengukur tingkat profitabilitas adalah Return On Asset (ROA). ROA adalah salah satu rasio keuangan yang bisa digunakan untuk mengukur sejauh mana kemampuan manajemen bank dalam memperoleh profit serta mengelola tingkat efisien usaha bank secara menyeluruh (Ponco, 2008).

\section{Capital Adequacy Ratio (CAR)}

Menurut Bank Indonesia (Nomor 9/13/PBI/2007), CAR adalah penyediaan modal minimum bagi bank didasarkan pada risiko aktiva dalam arti luas, baik aktiva yang tercantum dalam neraca maupun aktiva yang bersifat administratif sebagaimana tercermin pada kewajiban yang masih bersifat kontijen dan/atau komitmen yang disediakan oleh bank bagi pihak ketiga maupun risiko pasar. Hasibuan (2009) menambahkan CAR adalah salah satu cara untuk menghitung apakah modal yang ada pada suatu bank telah memadai atau belum.

\section{Diversifikasi Pendapatan}

Diversifikasi pendapatan adalah salah satu usaha perbankan dalam meningkatkan profitabilitas bank (Adiyati, 2013). Komponen utama pendapatan bank adalah bunga (interest income), dan pendapatan yang didapat oleh bank dari jasa perbankan (fee based) (Rinofah, 2014). Cakupan usaha yang termasuk dalam fee based antara lain: pendapatan provisi dan komisi, pendapatan transaksi devisa, dan pendapatan lainnya.

Jasa perbankan yang menghasilkan fee based antara lain bersumber dari berbagai kegiatan transfer, selain melalui kegiatan transfer bank juga dapat medapatkan fee based dari inkaso (Collection), Safe Defosit Box, kliring (Clearing), Letter of credit $(L / C)$, Credit card, dana pembayaran rekening titipan (payment point), garansi bank, jual beli atau perdagangan valuta asing.

Seperti halnya pada investasi yang dilakukan oleh individu, diversifikasi bermanfaat untuk mengurangi profil risiko bank (Smith et al., 2003). Apabila pendapatan dari operasional utama (bunga) tidak mencukupi untuk melunasi biaya operasional bank, maka pendapatan pendapatan di luar usaha inti ini dapat digunakan untuk menutupinya (Rinofah, 2014). Maka dari itu, dapat diambil kesimpulan bahwa semakin tinggifee-based maka semakin rendah ketergantungan bank terhadap pendapatan dari bunga sehingga risiko nya juga semakin rendah (Rinofah, 2018).

\section{Risiko Bank}

Risiko dalam konteks perbankan menurut Karim (2004) merupakan suatu kejadian potensial, baik yang dapat diperkirakan (anticipated) maupun yang tidak dapat diperkirakan (unanticipated) yang berdampak negatif terhadap pendapatan dan permodalan bank. Dalam penelitian, rasio yang digunakan untuk 
menilai tingkat risiko bank adalah Non Performing Loan (NPL). Menurut Ismail (2009) NPL adalah kredit yang menunggak melebihi 90 hari, dimana NPL terbagi menjadi kredit kurang lancar, diragukan dan macet. Semakin kecil NPL, maka semakin kecil pula risiko kredit yang ditanggung oleh pihak bank.

\section{Signaling Theory (Teori Sinyal)}

Teori sinyal menurut Brigham (2012) menjelaskan tentang tindakan yang diambil oleh manajemen perusahaan untuk memberikan petunjuk kepada para investor mengenai bagaimana cara pandang manajemen terhadap prospek perusahaan.

\section{Hipotesis}

\section{Pengaruh Negatif Profitabilitas Terhadap Risiko Bank}

Studi yang dilakukan oleh Kurniawan (2015), Lamen (2015) dan Kusuma (2016) menunjukkan hasil bahwa ROA berpengaruh negatif terhadap risiko bank. Menurut Syahyunan (2004) menjelaskan bahwa semakin besar ROA, mengindikasikan bahwa semakin besar tingkat keuntungan yang diperoleh oleh bank, sehingga menurunkan risiko suatu bank mengalami kondisi bermasalah. Maka dari itu, dapat disimpulkan bahwa semakin tinggi profitabilitas maka semakin rendah risiko banknya. Hal ini sejalan dengan teori sinyal, dimana ketika bank memiliki profit yang tinggi, maka bank dapat memenuhi kewajiban jangka pendek maupun jangka panjangnya, sehingga risiko kerugian yang akan ditanggung oleh bank akibat dari kredit macet semakin kecil.

H1: Profitabilitas berpengaruh negatif terhadap risiko bank.

\section{Pengaruh Negatif Capital Adequacy Ratio Terhadap Risiko Bank}

Penelitian yang dilakukan oleh Astrini (2014), Kumala (2015), Kusuma (2016), dan Rinofah (2018) menunjukan hasil bahwa CAR berpengaruh negatif terhadap risiko bank. Capital Adequacy Ratio (CAR) adalah rasio yang menunjukkan kemampuan bank dalam menggunakan modal sendiri tanpa memperoleh dana dari sumber diluar bank dalam membiayai seluruh aset yang mengandung resiko seperti penyaluran kredit, surat berharga, penyertaan dan tagihan pada bank lain (Dendawijaya, 2005). Hal ini sejalan dengan teori sinyal yang disampaikan oleh Brigham (2012), semakin besar modal yang dimiliki oleh suatu bank, maka semakin mudah bagi bank untuk membiayai aktiva yang mengandung risiko, sehingga risiko yang ditanggung bank menurun. Begitu juga sebaliknya, semakin kecil modal yang dimiliki oleh bank, maka akan meningkatkan risiko yang akan ditanggung oleh bank.

H2: Capital Adequacy Ratio berpengaruh negatif terhadap risiko bank.

\section{Pengaruh Negatif Diversifikasi Terhadap Risiko Bank}

Penelitian yang dilakukan oleh Rinofah (2014) menunjukan bahwa diversifikasi pendapatan berpengaruh negatif terhadap risiko bank. Menurut Sianipar (2015) dan Meslier (2013) menyimpulkan bahwa diversifikasi mampu menurunkan risiko pada suatu bank (risk taking). Hal ini disebabkan karena diversifikasi pendapatan diduga mampu meningkatkan profitabilitas perusahaan, sehingga dapat mengurangi tingkat risiko yang akan dialami oleh bank dari permasalahan seperti kredit macet.

H3: Diversifikasi pendapatan berpengaruh negatif terhadap risiko bank

4. Pengaruh Profitabilitas, Capital Adequacy Ratio, dan Diversifikasi Pendapatan Secara Simultan Terhadap Risiko Bank 
Berdasarkan beberapa hipotesis dan penjelasan di atas, peneliti menduga terdapat pengaruh secara simultan antara profitabilitas, capital adequacy ratio, dan diversifikasi pendapatan terhadap risiko bank pada perusahaan perbankan yang terdaftar di Bursa Efek Indonesia periode 2014-2018.

H4: Profitabilitas, Capital Adequacy Ratio, dan Diversifikasi Pendapatan Secara Bersama-sama (Simultan) Perpengaruh Signifikan Terhadap Risiko Bank.

\section{Model Penelitian}

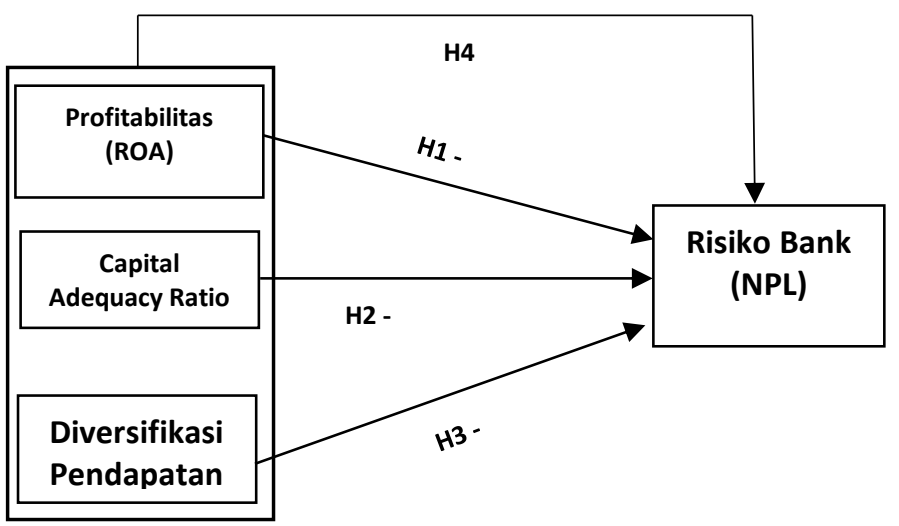

Gambar 1. Model Penelitian

METODE PENELITIAN

Populasi dalam penelitian ini merupakan perusahaan perbankan yang terdaftar di BEI tahun 2014-2018 yang berjumlah 43 perusahaan. Teknik pengambilan sampel yang digunakan adalah purposive sampling. Purposive sampling yaitu teknik penentuan sample dengan pertimbangan tertentu. Pertimbangan yang dilakukan oleh peneliti adalah:

a) Perusahaan perbankan yang terdaftar di BEI dari tahun 2014-2018

b) Menerbitkan laporan keuangan dari tahun 2014-2018 dan menyajikan data penghitungan rasio keuangan sesuai dengan variabel yang akan di teliti pada periode pengamatan

c) informasi yang terdapat dalam laporan tahunan atau laporan keuangan adalah laporan keuangan yang telah di audit

Berdasarkan kriteria tersebut, diperoleh 20 perusahaan yang memenuhi kriteria penelitian yang dilakukan selama periode lima tahun. Dengan demikian sampel dalam penelitian ini sebanyak 100 sampel. Penelitian ini menggunkan dua jenis variabel yaitu risiko bank yang di proksikan dengan Non Perfoming Loan (NPL) sebagai variabel dependen, profitabilitas (independen variabel), CAR (independen variabel), Diversifikasi pendapatan (independen variabel).

\section{Tabel 1.}

\section{Definisi Operasional Variabel Penelitian}

\begin{tabular}{ccl}
\hline \multicolumn{1}{c}{ Variabel } & Parameter & Sumber \\
\hline $\begin{array}{c}\text { Risiko Bank } \\
(\mathrm{Y})\end{array}$ & $\mathrm{NPL}=\frac{\text { total kredit bermasalah }}{\text { total kredit }} \times 100 \%$ & $\begin{array}{l}\text { Rinofah } \\
(2014)\end{array}$ \\
\hline $\begin{array}{c}\text { Profitabilitas } \\
(\mathrm{X} 1)\end{array}$ & $\mathrm{ROA}=\frac{\text { laba bersih }}{\text { total aktiva }} \times 100 \%$ & $\begin{array}{l}\text { Kurniawan } \\
(2015)\end{array}$ \\
\hline $\begin{array}{c}\text { CAR } \\
(\mathrm{X} 2)\end{array}$ & $\mathrm{CAR}=\frac{\text { Modal }}{\mathrm{ATMR}} \times 100$ & $\begin{array}{l}\text { Rinofah } \\
(2014)\end{array}$ \\
\hline $\begin{array}{c}\text { Diversifikasi } \\
\text { Pendapatan } \\
(\mathrm{X} 3)\end{array}$ & fee Based & $\begin{array}{l}\text { Rinofah } \\
(2014)\end{array}$ \\
\hline
\end{tabular}

Pengujian hipotesis dilakukan dengan menggunakan uji asumsi klasik yang terdiri dari uji normalitas, uji heteroskadastisitas, uji multikolinieritas dan uji autokorelasi. Uji regresi liner berganda, uji t, uji f dan koefisien detrminasi. Dengan persamaan model regresi $\widehat{Y}=a+b_{1} x 1+b_{2} X 2+b_{3} X 3$

Keterangan:

$\hat{Y} \quad=$ Risiko Bank

$\mathrm{X} 1=$ Profitabilitas (ROA)

$\mathrm{X} 2=\mathrm{CAR}$

$\mathrm{X} 3=$ Diversifikasi Pendapatan

a $=$ Konstanta 
HASIL PENELITIAN DAN PEMBAHASAN

\section{Uji Statistik Deskriptif}

Tabel 2

\begin{tabular}{lrrrrr}
\multicolumn{6}{c}{ Hasil Uji Statistik Deskriptif } \\
\hline & \multicolumn{1}{c}{ Min } & \multicolumn{1}{c}{ Max } & Mean & Deviation \\
\hline Profitabibilas & 100 & 0,09 & 4,74 & 1,933 & 1,114 \\
CAR & 100 & 11,61 & 34,93 & 20,053 & 4,210 \\
Diversifikasi & 100 & 0,02 & 0,52 & 0,139 & 0,125 \\
Risiko bank & 100 & 0,25 & 8,54 & 2,669 & 1,394 \\
Valid N & 100 & & & & \\
(listwise) & & & & & \\
\hline
\end{tabular}

Sumber: Olah Data SPSS 18

Analisa pada tabel 2 di atas menunjukan jumlah sampel sebanyak 100 dengan nilai minimum profitabilitas 0,09 , nilai maksimum 4,74, rata-rata 1,933 dengan standar deviation 1,114. Capital Adequacy Ratio memiliki nilai minimum 11,61 , nilai maksimum 34, 93, rata-rata20, 053 dengan standar deviation 4,210. Diversifikasi Pendapatan (fee based) memiliki nilai minimum 0,02 , nilai maksimum 0,52 , rata-rata 1,394 , dengan standar deviation 0,125. Risiko Bank memiliki nilai minimum 0,25 , nilai maksimum 8,54, rata-rata 2,669 dengan standar deviation 1,394.

\section{Uji Normalitas}

Tabel 3 Hasil Uji Normalitas

\begin{tabular}{lr}
\hline & \multicolumn{2}{c}{ Unstandardized } \\
& Residual \\
\hline Kolmogorov-Smirnov Z & .922 \\
Asymp. Sig. (2-tailed) & .363 \\
\hline
\end{tabular}

Sumber: Olah Data SPSS 18

Berdasarkan hasil uji normalitas pada tabel 3 di atas, dapat dilihat bahwa nilai kolmogrov-Smirnof adalah 0,922 , dan nilai signifikannya adalah $0,363>0,05$ yang berarti bahwa data tersebut berdistribusi normal.

\section{Uji Heterokedastisitas}

Tabel 4 Hasil Uji Heterokedastisitas

\begin{tabular}{llll}
\hline \multicolumn{2}{l}{ Model } & $\mathrm{t}$ & Sig. \\
\hline $1 \quad$ (Constant) & 3.594 & 0.001 \\
& Profitabilitas & -1.514 & 0.133 \\
& CAR & -0.308 & 0.759 \\
& Diversifikasi & -1.605 & 0.112 \\
\hline
\end{tabular}

Sumber: Olah Data SPSS 18

Tabel 4 di atas menunjukan bahwa nilai signifikan variabel independen lebih besar dari nilai signifikan 0,05. Variabel profitabilitas mempunyai nilai signifikan sebesar 0,133, variabel Capital Adecquacy Ratio mempunyai nilai signifikan sebesar 0,759, sedangkan variabel Diversifikasi (Fee Based) mempunyai nilai signifikan sebesar 0,112 yang berarti bahwa data tersebut tidak terjadi heteroskadesitas.

\section{Uji Multikolinearitas}

\section{Tabel 5}

Hasil Uji Multikolinearitas

\begin{tabular}{llcc}
\hline Model & \multicolumn{2}{c}{ Collinearity Statistics } \\
& & Tolerance & VIF \\
\hline 1 & (Constant) & & \\
& Profitabilitas & 0.786 & 1.273 \\
& CAR & 0.862 & 1.160 \\
& Diversifikasi & 0.848 & 1.179 \\
\hline
\end{tabular}

Sumber: Olah Data SPSS 18

Tabel 5 di atas menunjukan bahwa nilai Tolerance lebih besar dari 0,10 . Nilai Tolerance pada table 5 di atas yaitu 0,786 , $0,862,0,848$ sedangkan nilai VIF di bawah 10. Nilai Variance Inflation Factor (VIF) pada table 4 di atas menunjukan 1,273, $1,160,1,179$, yang berarti bahwa data di atas tidak mengalami multikolinieritas. 
5. Uji Autokorelasi

Tabel 6

Hasil Uji Autokorelasi

\begin{tabular}{lr}
\hline & Unstandardized \\
& Residual \\
\hline Test Value $^{\mathrm{a}}$ & -.15708 \\
Asymp. Sig. (2-tailed) & 0.421 \\
\hline
\end{tabular}

Sumber: Olah Data SPSS 18

Berdasarkan analisa dari tabel 6 di atas menunjukan bahwa nilai tes sebesar 0,15708 dengan tingkat signifikan sebesar 0,421 . Sehingga data pada tabel 6 di atas menunjukan tidak terjadi adanya gejala autokorelasi karena tingkat signifikanya lebih besar dari 0,05 .

\section{Uji Regresi Linear Berganda}

\section{Tabel 7}

Hasil Regresi Linear Berganda

\begin{tabular}{llcc}
\hline \multicolumn{2}{l}{ Model } & B & Sig. \\
\hline $1 \quad$ Constant) & 4.972 & 0.000 \\
& Profitabilitas & -.459 & 0.000 \\
& CAR & -.073 & 0.025 \\
& Diversifikasi & 0.317 & 0.770 \\
\hline
\end{tabular}

Sumber: Olah Data SPSS 18

Berdasarkan hasil model regresi pada table 7 di atas diperoleh hasil persamaan regresi linier berganda sebagai berikut:

$\mathrm{Y}=$ 4,972 - 0,459 Profitabilitas - 0,073 CAR $+0,317$ Diversifikasi $+\mathrm{e}$

\section{Uji Parsial (Uji T)}

\section{Tabel 8} Hasil Uji Parsial (Uji t)

\begin{tabular}{llcc}
\hline \multicolumn{2}{l}{ Model } & $\mathrm{T}$ & Sig. \\
\hline 1 & (Constant) & 7.696 & 0.000 \\
& Profitabilitas & -3.621 & 0.000 \\
& CAR & -2.273 & 0.025 \\
& Diversifikasi & 0.293 & 0.770 \\
\hline
\end{tabular}

Sumber: Olah Data SPSS 18
Berdasarkan analisa pada tabel 8 di atas dapat diketahui adanya pengaruh dalam model regresi secara parsial antara variabel independen terhadap variabel dependen. Berdasarkan analisa pada tabel di atas t-hitung dari profitabilitas menunjukan nilai sebesar -3,621 dengan tingkat signifikan 0,000 , yang berarti bahwa profitabilitas memiliki pengaruh signifikan dengan arah negatif terhadap risiko bank. Capital Adecuacy Ratio dalam tabel di atas menunjukan nilai t-hitung sebesar -2,273 dengan tingkat signifikan sebesar 0,025, sehingga dapat disimpulkan bahwa Capital Adecquacy Ratio memiliki pengaruh signifikan dengan arah negatif signifikan terhada risiko bank. Diversifikasi pendapatan dalam tabel di atas menunjukan nilai t-hitung sebesar 0,293 dengan tingkat signifikan sebesar 0,770, sehingga dapat disimpulkan bahwa diversifikasi pendapatan memiliki pengaruh positif namun tidak signifikan terhadan risiko bank.

\section{Uji Simultan (Uji F)}

\begin{tabular}{|c|c|c|}
\hline \multicolumn{3}{|c|}{$\begin{array}{c}\text { Tabel } 9 \\
\text { Hasil Uji Simultan (Uji F) }\end{array}$} \\
\hline Model & $\mathrm{F}$ & Sig. \\
\hline $\begin{array}{ll}1 & \begin{array}{l}\text { Regression } \\
\text { Residual }\end{array}\end{array}$ & 9.342 & $0.000^{\mathrm{a}}$ \\
\hline Total & & \\
\hline
\end{tabular}

Berdasarkan analisa pada tabel 9 di atas menunjukan bahwa F-hitung sebesar 9,342 > F tabel 2,70 Dan nilai signifikan sebesar $0,000<0,05$, sehingga hasil tersebut menunjukan bahwa secara bersama-sama variabel independen mempunyai pengaruh secara bersamasama (simultan) terhadap variabel dependen. 


\section{Uji Koefisien Determinasi $\left(\mathbf{R}^{2)}\right.$}

Tabel 10 Hasil Koefisien Determinasi $\left(\mathbf{R}^{2}\right)$

\begin{tabular}{ccccc}
\hline Model & & R & Adjusted R & $\begin{array}{c}\text { Std. Error } \\
\text { of the } \\
\end{array}$ \\
& $\mathrm{R}$ & Square & Square & Estimate \\
\hline 1 & $0,475^{\mathrm{a}}$ & 0,226 & 0,202 & 1,24595
\end{tabular}

Sumber: Olah data SPSS 18

Berdasarkan model regresi pada tabel 10 di atas menunjukan bahwa nilai adjusted $\left(\mathrm{R}^{2}\right)$ sebesar 0,202 berarti variabel bebas dalam penelitian ini dapat menjelaskan variabel risiko bank sebanyak $20,2 \%$ dimana selebihnya $79,8 \%$ dijelaskan oleh variabel lain yang tidak diuji dalam penelitian ini. Standar Error of Estimate (SEE) menunjukan nilai 1,24595. Sementara nilai $\mathrm{R}$ sebesar 0,475 menunjukan hubungan antara variabel dependen yaitu risiko bank dengan variabel independen yaitu profitabilitas, Capital Adequacy Ratio dan Diversifikasi pendapatan.

\section{Pembahasan}

Berdasarkan analisi data yang telah dilakukan, maka hasil uji hipotesis pada penelitian ini sebagai berikut:

\section{Pengaruh Negatif Profitabilitas Terhadap Risiko Bank}

Hasil uji statistik pertama menunjukan bahwa profitabilitas yang diukur menggunakan rasio Return On Asset (ROA) berpengaruh negatif terhadap risiko bank yang di ukur dengan menggunakan Non Perfoming Loan (NPL). Hasil penelitian menunjukan nilai t hitung $-3,621$ dan memiliki nilai signifikan 0,000 yang berarti kurang dari 0,05 . Hasil penelitian ini sejalan dengan penelitian yang dilakukan oleh Kurniawan (2015), Lamen (2015), dan Kusuma (2016) dimana hasil penelitian menunjukan bahwa profitabilitas (ROA) berpengaruh signifikan negatif terhadap risiko bank (NPL), sehingga dapat di simpulkan bahwa profitabilitas memiliki pengaruh negatif terhadap risiko bank yang diproksikan dengan Non Perfoming Loan (NPL) yang berarti hipotesis pertama diterima.

Menurut Syahyunan (2004) dalam semakin besar ROA maka semakin besar pula keuntungan yang diperoleh oleh bank, sehingga suatu bank dalam kondisi bermasalah maka semakin kecil keuntungannya. Maka dari itu, dapat di simpulkan bahwa semakin tinggi profitabilitas maka semakin rendah risiko banknya. Ketika bank memiliki profit yang tinggi, maka bank dapat memenuhi kewajiban jangka pendek maupun jangka panjangnya, sehingga risiko kerugian yang akan ditanggung oleh bank akibat kredit macet yang ditimbulkan karena nasabah tidak bisa melunasi kewajibanya semakin kecil. Hal ini juga sejalan dengan teori sinyal dari Brigham (2012), ketika prifitabilitas perusahaan meningkat, maka risiko yang ditanggung perusahaan akan menurun.

\section{Pengaruh Negatif Capital Adequacy Ratio (CAR) Terhadap Risiko Bank}

Hasil uji statistik kedua menunjukan bahwa Capital Adequacy Ratio (CAR) memiliki pengaruh negatif terhadap risiko bank (NPL). Hasil penelitian menunjukan bahwa t-hitung sebesar -2,273 dengan nilai signifikan sebesar 0,025 yang berarti kurang dari 0,05 . Penelitian ini sejalan dengan penelitian yang dilakukan oleh Astrini (2014), Kumala (2015), Kusuma (2016) dan Rinofah (2018) yang menyatakan bahwa Capital Adequacy Ratio memiliki pengaruh negatif terhadap risiko bank. Maka dari itu, dapat disimpulkan bahwa Capital Adequacy Ratio memiliki pengaruh negatif terhadap risiko bank (NPL) yang berarti hipotesis kedua diterima. 
Capital Adequacy Ratio (CAR) adalah rasio yang menunjukkan kemampuan bank dalam menggunakan modal sendiri tanpa memperoleh dana dari sumber diluar bank dalam membiayai seluruh aset yang mengandung resiko seperti penyaluran kredit, surat berharga, penyertaan dan tagihan pada bank lain (Dendawijaya, 2005). Selanjutnya, semakin tinggi modal yang dimiliki oleh suatu bank, maka semakin mudah bagi bank untuk membiayai aktiva yang mengandung risiko, begitu juga sebaliknya semakin tinggi risiko bank tanpa disertai dengan modal yang cukup, maka akan menimbulkan risiko bank yang tinggi. Penelitian ini menunjukan hasil bahwa modal yang dimiliki suatu bank yang diwakilkan dengan rasio CAR mampu menutupi risiko yang dihadapi oleh bank, termasuk risiko kredit yang diakibatkan karena adanya kredit bermasalah. Hal ini sejalan dengan teori sinyal yang dikemukakan Brigham (2012) dimana ketika persediaan modal perusahaan meningkat/cukup besar, maka akan menurunkan risiko yang akan ditanggung perusahaan.

\section{Pengaruh Negatif Diversifikasi Pendapatan Terhadap Risiko Bank}

Hasil uji statistik ketiga menunjukan bahwa diversifikasi pendapatan yang di proksikan dengan Fee based berpengaruh positif terhadap risiko bank (NPL). Hasil penelitian menunjukan bahwa $\mathrm{t}$ hitung sebesar 0,293 dengan nilai signifikan sebesar 0,770 yang berarti lebih besar dari 0,05 . Berdasarkan pengujian variabel divesifikasi pendapatan terhadap risiko bank (NPL) memiliki pengaruh positif berarti bahwa hipotesis ketiga ditolak. Hasil penelitian ini mendukung penelitian sebelumnya dari Rauf (2018) yang menunjukkan bahwa diversifikasi pendapatan berpengaruh positif tetapi tidak signifikan terhadap risiko bank.

Menurut Hahm (2008) feebased income tidak selamanya memberikan manfaat seperti peningkatan profitabilitas yang tinggi. Hal ini terjadi karena kegiatan yang berfokus pada fee based akan memperbesar biaya tetap yang dapat memperbesar risiko bank yang mana tidak diimbangi dengan pendapatan fee-nya sehingga membuat risiko yang dihadapi semakin besar.

\section{Pengaruh Profitabilitas, Capital} Adequacy Ratio, dan Diversifikasi Pendapatan Secara Simultan Terhadap Risiko Bank

Berdasarkan uji simultan (Uji F), menunjukkan hasil F-hitung sebesar 9,342 > F tabel 2,70, dan nilai signifikan sebesar $0,000<0,05$, sehingga kesimpulannya secara bersama-sama variabel independen (profitabilitas, capital adequacy ratio, dan diversifikasi pendapatan) mempunyai pengaruh secara bersama-sama (simultan) terhadap variabel dependen (risiko bank).

\section{PENUTUP}

\section{Kesimpulan}

Berdasarkan hasil analisa dan pembahasan dalam penelitian yang disertai dengan pembuktian berupa hipotesis mengenai profitabilitas, capital adequacy ratio dan diversifikasi pendapatan terhadap risiko bank, maka dapat diambil kesimpulan bahwa secara parsial profitabilitas memiliki pengaruh negatif terhadap risiko bank dengan nilia t sebesar -3,621 dan tingkat signifikan sebesar 0,000. Capital Adequacy Ratio secara parsial memiliki pengaruh negatif terhadap risiko bank dengan nilai t-hitung sebesar 2,273 dan tingkat signifikan sebesar 0,025 . Diversifikasi pendapatan secara parsial memiliki pengaruh positif tetapi tidak signifikan terhadap risiko bank dengan nilai t- 
hitung sebesar 0,293 dan tingkat signifikan sebesar 0,770 . Secara simultan profitabilitas (ROA), Capital Adequacy Ratio dan diversifikasi pendapatan (fee based) memiliki pengaruh dengan tingkat signifikan sebesar $0,000<0,05$. Hasil tersebut menunjukan bahwa secara simultan variabel independen berpengaruh secara simultan terhadap variabel dependen.

\section{Saran}

Berdasarkan dari hasil analisa penelitian yang telah dilakukan, maka peneliti memberikan saran bagi peneliti selanjutnya untuk mengembangkan variabel yang digunakan untuk mengukur risiko bank tidak hanya menggunkanan NPL saja. Untuk variabel profitabilitas bisa di ukur dengan variabel lain seperti ROE, jumlah sampel yang lebih banyak, dan tahun pengamatan yang berbeda untuk mendapatkan hasil yang menyeluruh.

\section{DAFTAR PUSTAKA}

Brigham, Eugene F dan Houston, J,F. (2012). Dasar-Dasar Manajemen Keuangan. Edisi Kesepuluh. Jakarta: Erlangga.

Dendawijaya, Lukman. (2005). Manajemen Perbankan. Bogor: Ghalia Indonesia.

Fahmi, Irham. (2011). Analisis Laporan Akuntansi. Bandung: Alfabeta.

Hahm, Joon H. (2008). Determinants and Consequences of Non-Interest Income Diversifi cation of Commercial Banks in OECD Countries. Journal of International Economic Studies, Vol.12 No.1: $3-32$.

Hasibuan, Malayu S.P.. (2009). Manajemen Sumber Daya Manusia. Jakarta: Bumi Aksara.
Ikatan Akuntan Indonesia. (2002). Standar Akuntansi Keuangan. Jakarta: Salemba Empat.

Karim, Adiwarman A.. (2004). Bank Islam Analisis Fiqih dan Keuangan. Jakarta: Raja Grafindo Persada.

Kasmir. (2008). Bank dan Lembaga Keuangan Lainnya. Edisi Revisi. Jakarta: Raja Grafindo Persada.

Kasmir. (2014). Analisis Laporan Keuangan. Edisi Pertama, Cetakan Ketujuh. Jakarta: Raja Grafindo Persada.

Kumala, P. A. S., \& Suryantini, N. P. S. (2015). Pengaruh Capital Adequacy Ratio, Bank Size Dan Bi Rate Terhadap Risiko Kredit (NPL) Pada Perusahaan Perbankan. E-Jurnal Manajemen, 4(8).

Kurniawan, Eki. (2015). Pengaruh LDR, CAR, BI RATE, BOPO Dan ROA Terhadap Tingkat Risiko Kredit Pada Bank Umum Go Public Di Indonesia (Studi Pada Bank Umum Go Public Yang Terdaftar Di Bursa Efek Indonesia Periode Tahun 2011-2014).

Kusuma, E. C., \& Haryanto, A. M. (2016). Analisis Pengaruh Variabel Kinerja Bank (CAR, ROA, BOPO dan LDR), Serta Pertumbuhan Kredit dan Kualitas Kredit Terhadap Non Performing Loan (NPL). Diponegoro Journal of Management, 5(4), 108-120

Lamen, S. R. M. (2015). Pengaruh Size, LDR, ROA, CAR dan Total Loan Terhadap Non Performing Loan Sektor Perbankan Yang Terdaftar Di Bursa Efek Indonesia. Doctoral Dissertation. Surabaya: STIE Perbanas.

Meslier, C., Tacneng, R., \& Tarazi, A. (2013). Bank Diversification, Risk and Profitability in an Emerging Economy 
with Regulatory Asset Structure Constraints: Evidence from the Philippines. Archives Ouvertes, 1-55.

Nusantara, Ahmad Buyung. (2009). Analisis Pengaruh NPL, CAR, LDR, dan BOPO Terhadap Prosfitabilitas Bank (Perbandingan Bank Umum Go Publik Dan Bank Umum Non Go Publik Di Indonesia Periode Tahun 2005-2007). Semarang: Universitas Diponegoro.

Peraturan Bank Indonesia nomor 5 tahun 2003.

Ponco, Budi. (2008). Analisis Pengaruh CAR, NPL, BOPO, NIM dan LDR Terhadap ROA (Studi Kasus Pada Perusahaan Perbankan yang Terdaftar di Bursa Efek Indonesia Periode 2004-2007). Semarang: Universitas Diponegoro.

Prasanjaya, A. Y., \& Ramantha, I. W. (2013). Analisis pengaruh rasio CAR, BOPO, LDR dan ukuran perusahaan terhadap profitabilitas bank yang terdaftar di BEI. E-Jurnal Akuntansi, 230-245.

Rauf, Abd. (2018). Struktur Kepemilikan, Diversifikasi Pendapatan, Dan Resiko Bank Di Indonesia. Thesis. Surabaya: Universitas Khatolik Widya Mandala.

Rinofah, R dan Diah Lestari Mumpuni. 2018. Pengaruh Diversifikasi Pendapatan Dan Kecukupan Modal Terhadap Tingkat Risiko Perbankan Bumn.Laporan Akhir Penelitian

Rinofah, R., Widaresti, A. L., \& Purbasari, N. D. (2018). Determinan Risk Taking Bank Perkreditan Rakyat Di Daerah Istimewa Yogyakarta. Jurnal Akuntansi \& Manajemen Akmenika Vol, 15(1).
Rinofah, Risal dan Prathama Nugraha. 2014. Pengaruh Konsentrasi Kepemilikan, dan Keterbukaan, Diversifikasi, Terhadap Risiko Bank. Jurnal Manajemen Volume 4 Nomor 2.s

Sianipar, Aryanti Sariartha. (2015). Pengaruh Diversifikasi Pendapatan Terhadap Kinerja Bank. Jurnal Siasat Bisnis Volume 19 Nomor. 1.

Syahyunan. (2004). Laporan Keuangan. Jakarta: Rajawali.

Undang-Undang Perbankan Nomor 10 Tahun 1998. 